\title{
GMR
}

\section{Inhibition of SHH pathway mechanisms by arsenic trioxide in pediatric medulloblastomas: a comprehensive literature review}

\author{
P.H.S. Klinger ${ }^{1}$, A.F. Andrade ${ }^{2}$, L.E.A. Delsin ${ }^{2}$, R.G.P. Queiroz ${ }^{1}$, \\ C.A. Scrideli ${ }^{1}$, L.G. Tone ${ }^{1,2}$ and E.T. Valera ${ }^{1}$ \\ ${ }^{1}$ Departamento de Pediatria, Faculdade de Medicina de Ribeirão Preto, \\ Universidade de São Paulo, Ribeirão Preto, SP, Brasil \\ ${ }^{2}$ Departamento de Genética, Faculdade de Medicina de Ribeirão Preto, \\ Universidade de São Paulo, Ribeirão Preto, SP, Brasil \\ Corresponding author: P.H.S. Klinger \\ E-mail: phsklinger@gmail.com
}

Genet. Mol. Res. 16 (1): gmr16019412

Received October 6, 2016

Accepted December 14, 2016

Published February 16, 2017

DOI http://dx.doi.org/10.4238/gmr16019412

Copyright $(C 2017$ The Authors. This is an open-access article distributed under the terms of the Creative Commons Attribution ShareAlike (CC BY-SA) 4.0 License.

\begin{abstract}
Recent innovations in the genomic understanding of medulloblastomas have provided new ways to explore this highly invasive malignant brain cancer arising from the cerebellum. Among the four different medulloblastoma subgroups described to date, the sonic hedgehog $(\mathrm{SHH})$ genetic pathway is the pathway activated in the tumorigenesis of medulloblastoma. SHH-related medulloblastomas are usually of nodular/desmoplastic histology and frequently occur in children under the age of three, an age group highly susceptible to the acute and long-term effects of treatment. Several new drugs aimed at SHH modulation are currently under development. This review focuses on the role of arsenic trioxide, a drug well established in clinical practice and probably an under-explored agent in medulloblastoma management, in the SHH pathway.
\end{abstract}

Key words: Medulloblastoma; Sonic-hedgehog; Brain cancer; Arsenic trioxide; Treatment 
P.H.S. Klinger et al.

\section{INTRODUCTION}

Tumors of the central nervous system (CNS) are amongst the most common pediatric neoplasias, representing about 20 to $23 \%$ of all childhood cancers. In some study series, CNS tumors have shown the highest mortality rates, only lower than those for lymphohematopoietic diseases (Rickert and Paulus, 2001; Kool et al., 2012).

Medulloblastomas (MB) are the most common malignant brain tumors in children, corresponding to approximately $20 \%$ of all brain tumors in children younger than 15 years and accounting for significant morbidity-mortality rates (Patel et al., 2014). In more than $80 \%$ of the cases, they occur as midline tumors primarily originating in the cerebellar vermis. Metastases may be present at diagnosis or occur later (de Bont et al., 2008; Korshunov et al., 2010; Wells et al., 2010). The incidence of MB peaks among 6- to 8-year-old children (Rickert and Paulus, 2001). As a function of their location and embryonic origin, MB tend to disseminate towards the subarachnoid space, giving rise to metastases by dissemination through the cerebrospinal fluid (Rickert and Paulus, 2001).

Histologically, MB can be divided into three subgroups: the classical histological type comprises $70 \%$ of all $\mathrm{MB}$; the anaplastic or large cell $\mathrm{MB}$ are those of the worst prognosis and lowest frequency (less than 5\% of cases); and desmoplastic/nodular type of MB, particularly those affecting infants, have the best chance of cure (Crawford et al., 2007).

\section{Advances in the molecular classification of medulloblastomas}

The molecular study of MB has revealed distinct genetic-molecular expression profiles among the different subgroups of the tumor. Current consensus is that there are at least four major molecular subgroups, denoted Wingless (WNT), Sonic Hedgehog (SHH), Group 3, and Group 4. Therefore, from the anatomopathological viewpoint, MB comprises a set of different subgroups that are part of the same neoplasia (Fellay et al., 2011; Northcott et al., 2011; Kool et al., 2012; Gerber et al., 2014).

The WNT subgroup, corresponding to $10 \%$ of all MB, has a major role in the somatic mutation of the CTNNB1 gene, which codes for the beta-catenin protein. When this protein is not degraded, it accumulates in the cytoplasm, stabilizes, and is then translocated to the nucleus. The accumulation of nuclear beta-catenin leads to the regulation of transcription of a series of target genes mainly involved in cell proliferation. This group may also show germinal mutations in the tumor suppressor $A P C$, as well as in chromosome 6 (monosomy). It usually affects older children with the classical histological subtype of $\mathrm{MB}$, with metastases seldom being present at diagnosis. Moreover, MB with mutations in $A P C$ are associated with Turcot syndrome (de Bont et al., 2008; Fellay et al., 2011; Gerber et al., 2014).

In most cases, the SHH subgroup shows somatic mutations in one or more genes of the SHH pathway (e.g., PTCH1, SUFU, or SMO), which contribute to its constitutive activation. Its histological subtype may be desmoplastic, extensively nodular or classic, and rarely, anaplastic. Its incidence is biphasic, with infants/preschoolers and young adults being affected. The prognosis for infants is excellent when the tumor histology is extensively nodular or desmoplastic. The current tendency in the treatment of this group in infants is to reduce the intensity of therapy in order to increase the likelihood of a cure and to lower the rate of morbidity. Additionally, the MB of the SHH group may be associated with Gorlin syndrome (de Bont et al., 2008; Fellay et al., 2011; Gerber et al., 2014).

Genetics and Molecular Research 16 (1): gmr16019412 
Subgroup 3 is almost totally diagnosed in children and very rarely in adults or adolescents. It shows a greater predisposition for males and greater occurrence of metastases at diagnosis. The prognosis for this group is reserved, with the tumor usually belonging to the large cell/anaplastic or classic histological subtypes. $M Y C$ is amplified in most cases. In the future, the genes involved in this pathway, as is the case for $M Y C$ and others, might become candidates for pharmacological target therapy (de Bont et al., 2008; Fellay et al., 2011; Gerber et al., 2014).

Subgroup 4 is the most common subgroup, occurs at all ages, can be metastatic at diagnosis, and its prognosis is intermediate. As is the case for group 3, there is no exact description of genetic predisposition. Although in most cases isochromosome 17 is a cytogenetic marker of this subgroup, this is still a poorly characterized group from a molecular viewpoint compared to all the other MB subgroups (de Bont et al., 2008; Fellay et al., 2011; Gerber et al., 2014).

Analysis of the overall survival of patients with these MB subgroups showed that survival of up to 5 years has been observed in up to $90 \%$ of children with the WNT subgroup, as opposed to that observed in $39-58 \%$ of children with the 3 and 4 subgroups. This rate of survival depends on the age at tumor occurrence, presence of metastases, and unfavorable coexisting cytogenetic changes. Patients with the SHH subgroup of MB have an intermediate survival rate, while it is particularly longer among infants with the SHH subgroup. This finding is probably associated with the high frequency of desmoplastic histology among SHH tumors in infants since desmoplastic/nodular histology is an isolated marker of favorable prognosis in this age group (Northcott et al., 2011; Fellay et al., 2011; Kool et al., 2012). Conversely, patients with the SHH subgroup who do not present desmoplastic/nodular histology have a poorer survival rate. This subgroup of MB patients, along with group 3 patients, require new therapeutic approaches that could improve their chance at a cure and reduce the side effects caused by current treatment methods (Northcott et al., 2011; Fellay et al., 2011; Kool et al., 2012).

\section{Hedgehog signaling pathway}

Activation of the SHH signaling pathway is essential during embryonic development for the formation of different tissues and organs. Following this period, the pathway contributes to homeostasis and repair of adult tissues by maintaining stem and progenitor cells and control of cell proliferation and fate. However, when this pathway is activated aberrantly, it could lead to tumor development in different organs (De Smaele et al., 2008).

$\mathrm{MB}$ represents one of the different types of tumors that may originate from $\mathrm{SHH}$ pathway deregulation (Fellay et al., 2011). This pathway is responsible for the proliferation of cerebellar cells during development, and the maintenance of its activation after the embryonic period may give rise to MB (Fellay et al., 2011; Gerber et al., 2014).

The SHH pathway may be activated through signaling by specific ligands and by mutation of the pathway components. The three main ligands that are classified as morphogenic are Sonic hedgehog (SHH), Desert hedgehog (DHH), and Indian hedgehog (IHH); the first being the one most extensively studied (Buczkowicz et al., 2011).

SHH protein has an initial molecular weight of $45 \mathrm{kDa}$ and autocatalytic activity and may be cleaved into two portions, N-terminal and C-terminal (20 kDa and $25 \mathrm{kDa}$, respectively) (Shahi et al., 2012). The carboxyl group at the N-terminal of SHH undergoes a change, forming cholesterol that facilitates its binding, secretion, and transit activities. Involvement of the Dispatched protein is necessary for the paracrine action of SHH. When SHH binds to the patched 1 (PTCH1) transmembrane receptor, smoothened (SMO) (a receptor usually inhibited

Genetics and Molecular Research 16 (1): gmr16019412 
by PTCH1) is released, undergoes a conformational change, and translocates to the cytoplasm. SMO binds to suppressor of fused homolog (SUFU) in the cytoplasm, consequently releasing proteins belonging to the GLI family. These proteins, GLI1 (activator), GLI 2 (activator), and GLI 3 (inhibitor), translocate to the nucleus, where they act as transcription factors that regulate the expression of different targets such as GLI1, PTCH1, CYCLINE D, and MYC involved in cell survival, proliferation, and differentiation (Figure 1) (Buczkowicz et al., 2011).

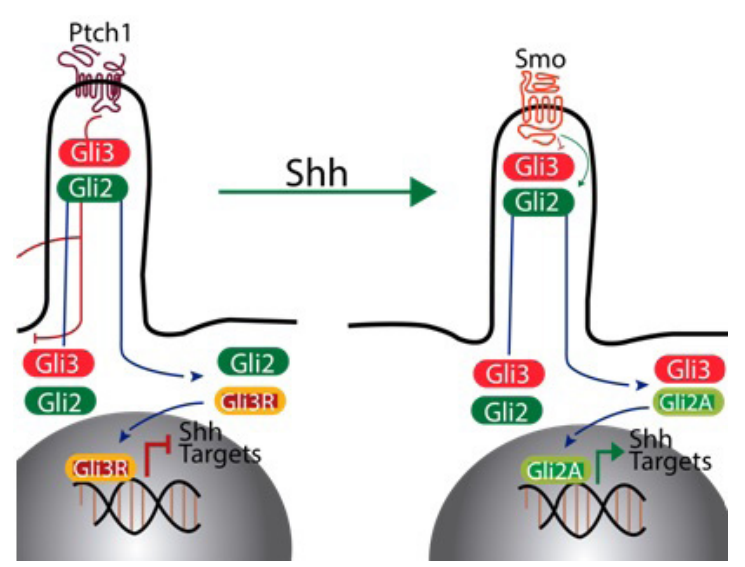

Figure 1. Schematic representation of the SHH transmembrane signaling pathway (Based on Han and AlvarezBuylla, 2010).

Another mechanism leading to the activation of the SHH pathway is the mutation of inhibitory regulatory genes. An example of this mechanism is somatic mutation and loss of heterozygosity in the gene that codes for the PTCH1 homologue (Robinson et al., 2015). As is the case for the other components of the SHH signaling pathway, the PTCH1 mutation seems to be sufficient for the development of MB. PTCH mutations have been reported in a subset of pediatric MB (Raffel et al., 1997), with the observed mutations affecting both the germinal and somatic cell lines, particularly in SUFU (Taylor et al., 2002). The downstream activity of the GLI protein family is intimately linked to tumorigenesis. The inactivation of both GLI alleles has been reported to lead to MB formation in mice heterozygous for $P T C H$, suggesting that SHH signaling may direct tumorigenesis in an independent manner (Raffel et al., 1997).

Even though similar mutation levels are observed in the four groups under study, the genetic sequencing of MB suggests that the different disease types affect individuals belonging to different age brackets (Fellay et al., 2011; Gerber et al., 2014). SUFU and SMO mutations have most frequently been detected in infants and adults, respectively. TP53 mutations have been detected in almost $50 \%$ of patients aged $4-17$ years. These results suggest that the treatment of $\mathrm{MB}$ can be better directed by considering the patient age range and genetic alteration present (Taylor et al., 2002; Kool et al., 2012).

\section{Arsenic trioxide (ATO)}

The therapeutic application of arsenic has a prodigious history. Knowledge of its medicinal benefits dates back to 400 B.C., with reports on its use by Hippocrates, Aristoteles, Dioscorides, and Pliny (Au, 2011). 
ATO is a known drug that has been studied and used to treat different diseases. Its carcinogenic action is believed to have been observed first in Paris (1822), where cattle grazing in the proximity of foundries developed neoplasias in their flanks. The onset of these tumors was attributed to gases impregnated with large amounts of these substances emitted by the foundries. In 1888, Hutchinson reported six cases of skin cancer in patients who had ingested arsenic for the treatment of dermatoses, to the London Pathology Society ( $\mathrm{Au}, 2011$ ). Interestingly, ATO was also used on battlefields in World War II in the form of a lethal gas called Lewisite in honor of the American chemist W. Lee Lewis (Au, 2011).

After decades of minimal use, it is interesting to note that ATO emerged again in the 21 st century as one of the drugs used for the treatment of acute promyelocytic leukemia M3, refractory to first line treatment, with promising results (Nasr et al., 2008).

ATO is a metal element known to exert its biological effect by direct interaction of its trivalent anion $\mathrm{AsO}_{3}^{-}$and the thiol groups of cysteines in the proximity of target proteins (Nasr et al., 2008) (Figure 2).

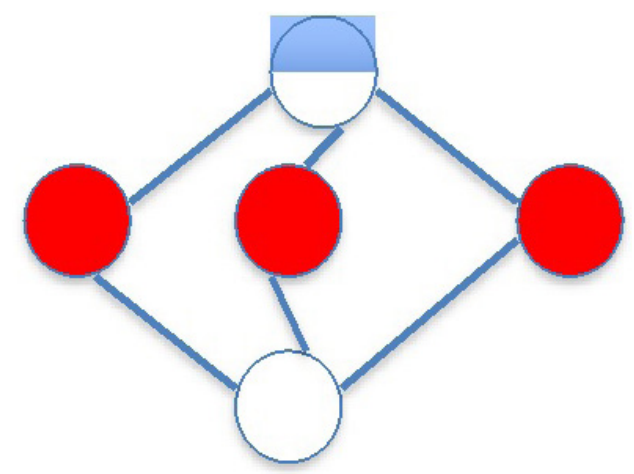

Figure 2. Chemical structure of arsenic trioxide $\left(\mathrm{As}_{2} \mathrm{O}_{3}\right)$ (Based on $\left.\mathrm{Au}, 2011\right)$.

In the $\mathrm{Zn}$-finger protein involved in acute promyelocytic anemia (PML), the N-terminal domain is rich in cysteine and includes a principal ring (R) and a helix domain (Lu et al., 2007).

In a study of patients with PML with CNS relapse or under intrathecal prophylaxis, $\mathrm{Au}$ (2011) demonstrated that enterally administered arsenic reached a satisfactory concentration in the CNS. The author also demonstrated a correlation between serum and cerebrospinal fluid levels of ATO, with the CNS concentration being $17.7 \%$ of the plasma level.

ATO has been approved by the food and drug administration for the treatment of PML. This drug shows good permeability in the CNS and is implicated in the inhibition of a central pathway of genes activated in MB. Overall, all of these characteristics cause ATO to be a considerably attractive drug for the study of its therapeutic potential against MB of the SHH subgroup in vitro and in animal models (Nakamura et al., 2013).

\section{MATERIAL AND METHODS}

This is an integrative literature review and conducted in order to answer the following guiding question: Which inhibitory mechanism of subgroup 2 of medulloblastoma (SHH) involves the Gli gene? To this end, a bibliographic study was performed using four databases:

Genetics and Molecular Research 16 (1): gmr16019412 
PUBMED (United States National Library of Medicine), BVS (Biblioteca Virtual em Saúde), WEB OF SCIENCE (Institute for Scientific Information-ISI), and EMBASE (Excerpta Medica Database). The investigation was carried out in March 2016 based on a time cut-off of 10 years for the inclusion of articles.

The controlled key words were used for the search were "medulloblastoma", "sonic hedgehog protein", and "regulatory mechanism" and the consequent uncontrolled key words are listed in Table 1. There was wide variation in the different databases, mainly regarding the uncontrolled key words, as shown in Table 1. The Boolean operator $A N D$ was used among the controlled key words, and $O R$ was used among the uncontrolled key words.

The following criteria were used for the inclusion of articles in the study: primary full papers dealing with inhibitory mechanisms of the SHH pathway of MB subgroup 2 involving Gli1; and papers published in Portuguese, English, and Spanish. Article exclusion criteria: letters, editorials, case reports, pilot studies, and papers whose subjects dealt with inhibition of other subgroups. The endNote X7 software (Thomson Reuters) was used as an instrument aiding the search of papers and references.

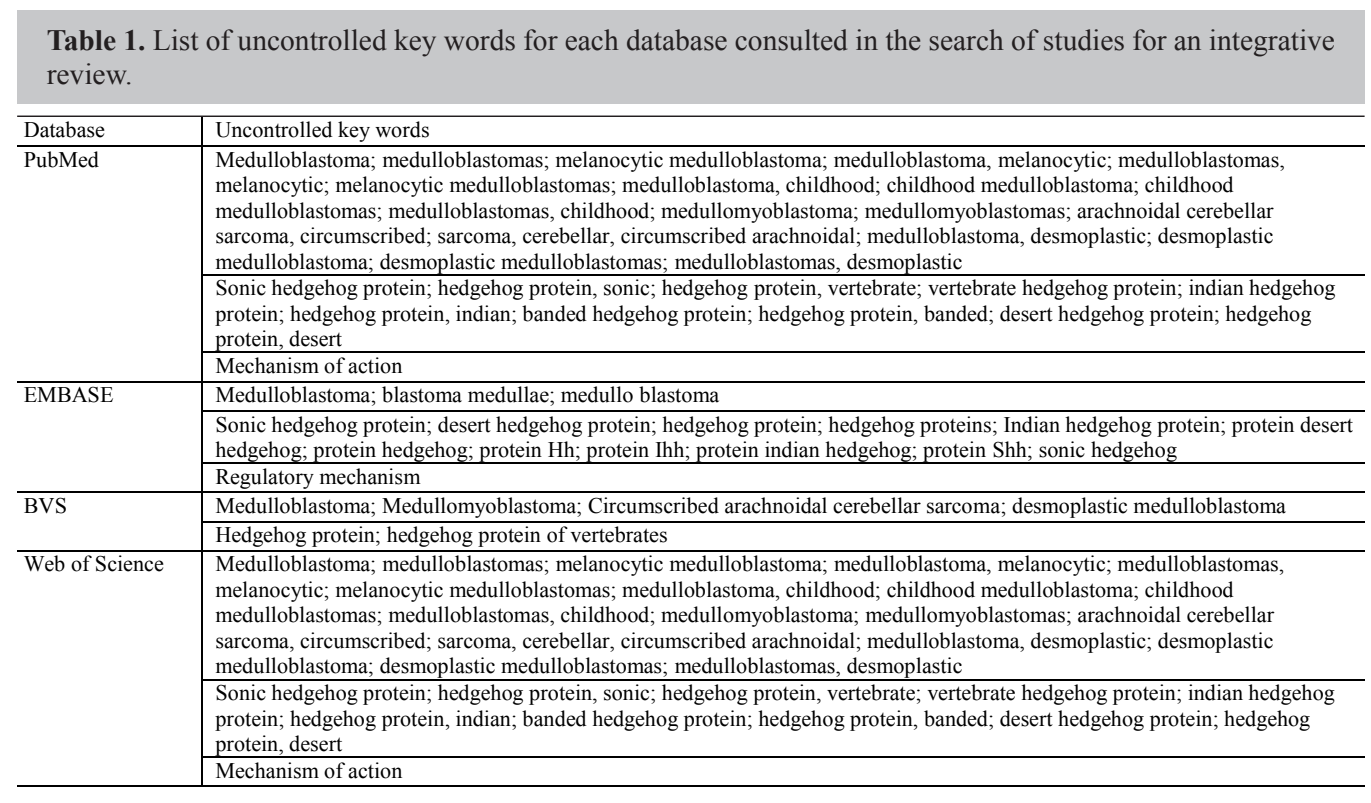

\section{RESULTS}

A total of 634 records were detected in the different databases used. Thirty-seven records were first excluded owing to duplication, and the exclusion of 551 publications was based on criteria described at Material and Methods section. Therefore, 46 full papers were selected. Of these, 40 were assessed for eligibility, with a final exclusion of 6 papers since they did not contain answers to the guiding question. The PRISMA diagram (Figure 3) details the methodology for the selection of articles for the review, (Table 2). 


\section{PRISMA 2009 Flow Diagram}
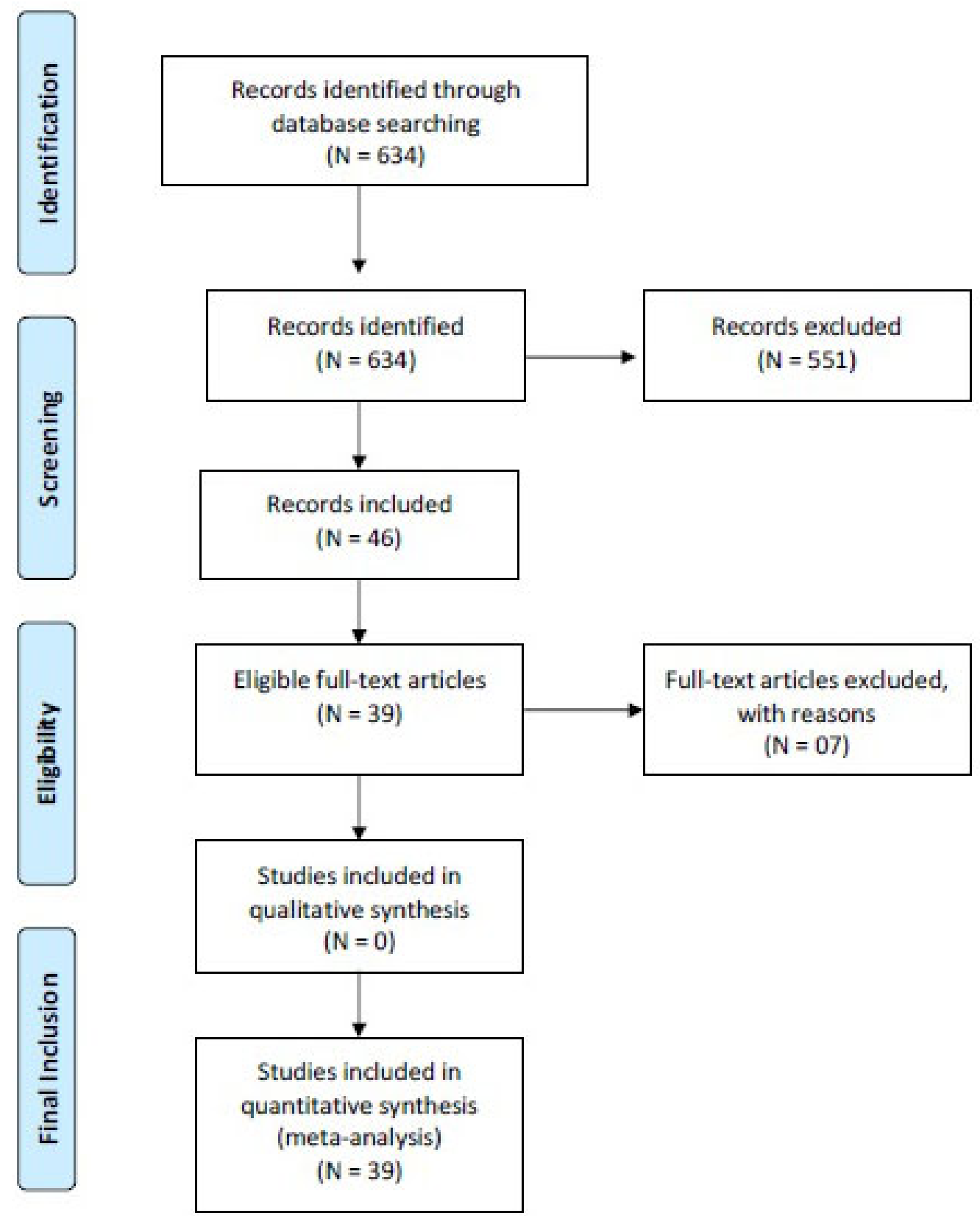

Figure 3. PRISMA flow diagram detailing the sample selection process of articles for the review.

Genetics and Molecular Research 16 (1): gmr16019412 
Table 2. List of the primary studies included in this integrative review with their author/s, title, year of publication, study method, and study classification.

\begin{tabular}{|c|c|c|c|c|c|}
\hline Study & Authors & Study title & Year of publication & Methods, series, and main findings & Type of study \\
\hline 1 & Al-Halabi et al. & $\begin{array}{l}\text { Preponderance of sonic } \\
\text { hedgehog pathway } \\
\text { activation characterizes } \\
\text { adult medulloblastoma }\end{array}$ & $\begin{array}{l}2011 \\
\text { Acta Neuropathol. }\end{array}$ & $\begin{array}{l}\text { A study of } 31 \text { samples of medulloblastomas } \\
\text { occurring in adults in order to establish the } \\
\text { biological characteristics and differences } \\
\text { from pediatric medulloblastomas. These } \\
\text { particularities can be considered for the } \\
\text { choice of therapy for this group }\end{array}$ & $\begin{array}{l}\text { Functional assays } \\
\text { and study of the } \\
\text { biological } \\
\text { characteristics of } \\
\text { medulloblastomas } \\
\text { occurring in } \\
\text { adults }\end{array}$ \\
\hline 2 & Au et al. & $\begin{array}{l}\text { Determinants of } \\
\text { cerebrospinal fluid arsenic } \\
\text { concentration in patients } \\
\text { with acute promyelocytic } \\
\text { leukemia on oral arsenic } \\
\text { trioxide therapy }\end{array}$ & $\begin{array}{l}2008 \\
\text { Blood }\end{array}$ & $\begin{array}{l}\text { Patients with AML M3 and CNS relapse or } \\
\text { undergoing chemoprophylaxis with ATO } \\
\text { were monitored and the plasma and CSF } \\
\text { concentrations of ATO were determined }\end{array}$ & Clinical study \\
\hline 3 & $\mathrm{Au}$ & $\begin{array}{l}\text { A biography of arsenic } \\
\text { and medicine in Hong } \\
\text { Kong and China }\end{array}$ & $\begin{array}{l}2011 \\
\text { Hong Kong Med. J. }\end{array}$ & Historical review of the use of ATO & Review article \\
\hline 4 & $\mathrm{Au}$ at al. & $\begin{array}{l}\text { Oral arsenic trioxide for } \\
\text { relapsed acute } \\
\text { promyelocytic leukemia } \\
\text { in pediatric patients }\end{array}$ & $\begin{array}{l}2012 \\
\text { Pediatr. Blood Cancer }\end{array}$ & $\begin{array}{l}\text { Four patients with AML M3 relapse were } \\
\text { treated with oral ATRA + ATO and all of } \\
\text { them had molecular remission }\end{array}$ & Case series report \\
\hline 5 & Beauchamp et al. & $\begin{array}{l}\text { GLI1 is a direct } \\
\text { transcriptional target of } \\
\text { EWS-FLI1 oncoprotein }\end{array}$ & $\begin{array}{l}2009 \\
\text { J. Biol. Chem. }\end{array}$ & $\begin{array}{l}\text { Functional assays with Ewing sarcoma cell } \\
\text { lines }\end{array}$ & $\begin{array}{l}\text { Preclinical study, } \\
\text { functional assays } \\
\text { with cell cultures }\end{array}$ \\
\hline 6 & Beauchamp et al. & $\begin{array}{l}\text { Arsenic trioxide inhibits } \\
\text { human cancer cell growth } \\
\text { and tumor development in } \\
\text { mice by blocking } \\
\text { Hedgehog/GLI pathway }\end{array}$ & $\begin{array}{l}2011 \\
\text { J. Clin. Invest. }\end{array}$ & $\begin{array}{l}\text { Functional assays with Ewing sarcoma cell } \\
\text { lines and a xenographic model in animal } \\
\text { models }\end{array}$ & $\begin{array}{l}\text { Preclinical study, } \\
\text { functional assays } \\
\text { with cell cultures } \\
\text { and animal } \\
\text { models }\end{array}$ \\
\hline 7 & Boehme et al. & $\begin{array}{l}\text { Targeting hedgehog } \\
\text { signalling by arsenic } \\
\text { trioxide reduces cell } \\
\text { growth and induces } \\
\text { apoptosis in } \\
\text { rhabdomyosarcoma } \\
\end{array}$ & $\begin{array}{l}2016 \\
\text { Int. J. Oncol. }\end{array}$ & $\begin{array}{l}\text { Functional assays with rhabdomyosarcoma } \\
\text { cell lines }\end{array}$ & $\begin{array}{l}\text { Preclinical study, } \\
\text { functional assays } \\
\text { with cell cultures }\end{array}$ \\
\hline 8 & Bont et al. & $\begin{array}{l}\text { Biological background of } \\
\text { pediatric } \\
\text { medulloblastoma and } \\
\text { ependymoma: a review } \\
\text { from a translational } \\
\text { research perspective }\end{array}$ & $\begin{array}{l}2008 \\
\text { Neuro Oncol }\end{array}$ & $\begin{array}{l}\text { Review article with emphasis on the } \\
\text { biology of the pediatric tumor } \\
\text { medulloblastoma and ependymoma and } \\
\text { future perspectives }\end{array}$ & Review article \\
\hline 9 & Buczkowicz et al. & $\begin{array}{l}\text { GLI2 is a potential } \\
\text { therapeutic target in } \\
\text { pediatric } \\
\text { medulloblastoma }\end{array}$ & $\begin{array}{l}2011 \\
\text { J. Neuropathol. Exp. } \\
\text { Neurol. }\end{array}$ & $\begin{array}{l}\text { Functional assays for determination of the } \\
\text { action of ATO in the GLI family, } \\
\text { correlating GLI concentrations with the } \\
\text { survival of } 124 \text { patients }\end{array}$ & $\begin{array}{l}\text { Functional assays } \\
\text { and survival } \\
\text { analysis }\end{array}$ \\
\hline 10 & Chang et al. & $\begin{array}{l}\text { Arsenic trioxide inhibits } \\
\text { cancer stem-like cells via } \\
\text { down-regulation of Gli1 } \\
\text { in lung cancer }\end{array}$ & $\begin{array}{l}2016 \\
\text { Am J Transl Res }\end{array}$ & $\begin{array}{l}\text { Functional assays with lung cancer cell } \\
\text { lines of the small cell type and observation } \\
\text { of the action of ATO on these cell lines and } \\
\text { on tumoral stem cells }\end{array}$ & $\begin{array}{l}\text { Functional assays } \\
\text { with cell lines }\end{array}$ \\
\hline 11 & Crawford et al. & $\begin{array}{l}\text { Medulloblastoma in } \\
\text { childhood: new biological } \\
\text { advances }\end{array}$ & $\begin{array}{l}2007 \\
\text { Lancet Neurol }\end{array}$ & $\begin{array}{l}\text { Literature review regarding new biological } \\
\text { advances in the treatment of } \\
\text { medulloblastomas } \\
\text { Greater understanding of the molecular } \\
\text { biology of medulloblastoma is needed } \\
\text { As newer biological agents are translated } \\
\text { from the lab to the bisede, clinicians need to } \\
\text { understand the fundamental signaling } \\
\text { pathways that are target during therapy }\end{array}$ & Review article \\
\hline 12 & Elamin et al. & $\begin{array}{l}\text { Curcumin inhibits the } \\
\text { Sonic Hedgehog signaling } \\
\text { pathway and triggers } \\
\text { apoptosis in } \\
\text { medulloblastoma cells }\end{array}$ & $\begin{array}{l}2010 \\
\text { Mol. Carcinog. }\end{array}$ & $\begin{array}{l}\text { Curcumin reduced beta-catenin levels and } \\
\text { activated the phosphorylated form of Akt } \\
\text { and NF- kappa B, leading to negative } \\
\text { regulation of the three main common } \\
\text { effectors, i.e., C-myc, N-myc, and cyclin } \\
\text { D1. Consequently, apoptosis was triggered } \\
\text { by curcumin through the mitochondrial } \\
\text { pathway by the negative regulation of the } \\
\text { Bcl-2 protein, an antiapoptotic downstream } \\
\text { effector of Shh }\end{array}$ & $\begin{array}{l}\text { Functional assays } \\
\text { using the drug } \\
\text { curcumin }\end{array}$ \\
\hline
\end{tabular}

Continued on next page

Genetics and Molecular Research 16 (1): gmr16019412 


\begin{tabular}{|c|c|c|c|c|c|}
\hline Study & Authors & Study title & Year of publication & Methods, series, and main findings & Type of study \\
\hline & & & & $\begin{array}{l}\text { signaling. Importantly, the resistant cells } \\
\text { that did not exhibit any reduction of Shh or } \\
\text { Bcl-2 levels were sensitized to curcumin by } \\
\text { the addition of the Shh antagonist } \\
\text { cyclopamine }\end{array}$ & \\
\hline 13 & Enguita-Germán et al. & $\begin{array}{l}\text { CD133+ cells from } \\
\text { medulloblastoma and } \\
\text { PNET cell lines are more } \\
\text { resistant to cyclopamine } \\
\text { inhibition of the sonic } \\
\text { hedgehog signaling } \\
\text { pathway than CD133- } \\
\text { cells }\end{array}$ & $\begin{array}{l}2010 \\
\text { Tumour Biol. }\end{array}$ & $\begin{array}{l}\text { Functional assays with cell lines using } \\
\text { positive and negative CD133 lines, and a } \\
\text { search of inhibitors of the SHH pathway } \\
\text { and its sensitivity to tumoral stem cells }\end{array}$ & $\begin{array}{l}\text { Functional assays } \\
\text { with cell lines }\end{array}$ \\
\hline 14 & Falchi et al. & $\begin{array}{l}\text { The evolution of arsenic } \\
\text { in the treatment of acute } \\
\text { promyelocytic leukemia } \\
\text { and other myeloid } \\
\text { neoplasms: Moving } \\
\text { toward an effective oral, } \\
\text { outpatient therapy }\end{array}$ & $\begin{array}{l}2015 \\
\text { Cancer }\end{array}$ & $\begin{array}{l}\text { The authors discuss the oral use of ATO in } \\
\text { AL subtype M3 and other types of myeloid } \\
\text { leukemia }\end{array}$ & Review article \\
\hline 15 & Fellay et al. & $\begin{array}{l}\text { Medulloblastomas in } \\
\text { adults: prognostic factors } \\
\text { and lessons from } \\
\text { paediatrics }\end{array}$ & $\begin{array}{l}2011 \\
\text { Curr. Opin. Neurol. }\end{array}$ & $\begin{array}{l}\text { Review article with emphasis on the } \\
\text { biological markers of each } \\
\text { medulloblastoma subgroup, the prognosis } \\
\text { for each group, as well as treatment }\end{array}$ & Review article \\
\hline 16 & Hong-yan et al. & $\begin{array}{l}\text { VEGFA expression is } \\
\text { inhibited by arsenic } \\
\text { trioxide in HUVECs } \\
\text { through the upregulation } \\
\text { of Ets- } 2 \text { and miRNA-126 }\end{array}$ & $\begin{array}{l}2015 \\
\text { PLoS One }\end{array}$ & $\begin{array}{l}\text { Investigation of the mechanism by which } \\
\text { ATO inhibits VEGFA in HUVEC through } \\
\text { the upregulation of miRNA-126 }\end{array}$ & $\begin{array}{l}\text { Functional assays } \\
\text { with cell lines }\end{array}$ \\
\hline 17 & Gerber et al. & $\begin{array}{l}\text { Recent developments and } \\
\text { current concepts in } \\
\text { medulloblastoma }\end{array}$ & $\begin{array}{l}2014 \\
\text { Cancer Treatment } \\
\text { Reviews }\end{array}$ & $\begin{array}{l}\text { Literature review on new biological } \\
\text { advances in treatment }\end{array}$ & Review article \\
\hline 18 & Götschel et al. & $\begin{array}{l}\text { Synergism between } \\
\text { Hedgehog-GLI and EGFR } \\
\text { signaling in Hedgehog- } \\
\text { responsive human } \\
\text { medulloblastoma cells } \\
\text { induces downregulation } \\
\text { of canonical Hedgehog- } \\
\text { target genes and stabilized } \\
\text { expression of GLI1 }\end{array}$ & $\begin{array}{l}2013 \\
\text { PLoS One }\end{array}$ & $\begin{array}{l}\text { Investigation of the canonical SHH/GLI } \\
\text { pathway by intervention between } \mathrm{HH} \text { and } \\
\text { EGF }\end{array}$ & $\begin{array}{l}\text { Functional assays } \\
\text { with cell lines }\end{array}$ \\
\hline 19 & Han et al. & $\begin{array}{l}\text { Arsenic trioxide inhibits } \\
\text { viability of pancreatic } \\
\text { cancer stem cells in } \\
\text { culture and in a xenograft } \\
\text { model via binding to } \\
\text { SHH-Gli }\end{array}$ & $\begin{array}{l}2013 \\
\text { Onco. Targets Ther. }\end{array}$ & $\begin{array}{l}\text { Demonstration of the in vitro and in vivo } \\
\text { action of ATO using pancreatic cancer cell } \\
\text { lines }\end{array}$ & $\begin{array}{l}\text { Preclinical study, } \\
\text { functional assays } \\
\text { with cell lines and } \\
\text { animal models }\end{array}$ \\
\hline 20 & Han and Alvarez-Buylla & $\begin{array}{l}\text { Role of primary cilia in } \\
\text { brain development and } \\
\text { cancer }\end{array}$ & $\begin{array}{l}2009 \\
\text { Curr. Opin. } \\
\text { Neurobiol. }\end{array}$ & $\begin{array}{l}\text { Review article about primary cilia and } \\
\text { defects associated with genetic syndromes } \\
\text { and tumorigenesis }\end{array}$ & Review article \\
\hline 21 & Kim et al. & $\begin{array}{l}\text { Arsenic antagonizes the } \\
\text { Hedgehog pathway by } \\
\text { preventing ciliary } \\
\text { accumulation and } \\
\text { reducing stability of the } \\
\text { Gli2 transcriptional } \\
\text { effector }\end{array}$ & $\begin{array}{l}2010 \\
\text { Proc. Natl. Acad. Sci. }\end{array}$ & $\begin{array}{l}\text { ATO as an antagonist of the SHH pathway } \\
\text { prevents cilia accumulation and reduces } \\
\text { Gli2 stability in transcription }\end{array}$ & $\begin{array}{l}\text { Preclinical study, } \\
\text { functional assays } \\
\text { with cell cultures } \\
\text { and animal } \\
\text { models }\end{array}$ \\
\hline 22 & Kool et al. & $\begin{array}{l}\text { Molecular subgroups of } \\
\text { medulloblastoma: an } \\
\text { international meta- } \\
\text { analysis of transcriptome, } \\
\text { genetic aberrations, and } \\
\text { clinical data of WNT, } \\
\text { SHH, Group 3, and Group } \\
4 \text { medulloblastomas }\end{array}$ & $\begin{array}{l}2012 \\
\text { Acta Neuropathol. }\end{array}$ & $\begin{array}{l}\text { International meta-analysis of } \\
\text { transcriptome, genetic aberrations, and } \\
\text { clinical data of WNT, SHH, Group 3, and } \\
\text { Group with new biological advances in the } \\
\text { treatment of medulloblastomas }\end{array}$ & Review article \\
\hline
\end{tabular}


P.H.S. Klinger et al.

Table 2. Continued.

\begin{tabular}{|c|c|c|c|c|c|}
\hline Study & Authors & Study title & Year of publication & Methods, series, and main findings & Type of study \\
\hline 23 & Korshunov et al. & $\begin{array}{l}\text { Adult and pediatric } \\
\text { medulloblastomas are } \\
\text { genetically distinct and } \\
\text { require different } \\
\text { algorithms for molecular } \\
\text { risk stratification }\end{array}$ & $\begin{array}{l}2010 \\
\text { J. Clin. Oncol. }\end{array}$ & $\begin{array}{l}\text { Analysis of medulloblastomas occurring in } \\
\text { the adult age range and detection of } \\
\text { markers differing from those of } \\
\text { medulloblastomas occurring in children. } \\
\text { This study states the need for different } \\
\text { treatments for adults }\end{array}$ & $\begin{array}{l}\text { Functional assays, } \\
\text { evaluation of } \\
\text { biological } \\
\text { markers, survival } \\
\text { curve }\end{array}$ \\
\hline 24 & Leonard et al. & $\begin{array}{l}\text { Sonic Hedgehog signaling } \\
\text { impairs ionizing } \\
\text { radiation-induced } \\
\text { checkpoint activation and } \\
\text { induces genomic } \\
\text { instability }\end{array}$ & $\begin{array}{l}2008 \\
\text { J. Cell. Biol. }\end{array}$ & $\begin{array}{l}\text { The results suggest that inappropriate SHH } \\
\text { activation promotes tumorigenesis by } \\
\text { deactivating a key signaling pathway that } \\
\text { helps maintain genomic stability and } \\
\text { inhibits tumorigenesis }\end{array}$ & $\begin{array}{l}\text { Preclinical study, } \\
\text { functional assays } \\
\text { with cell cultures } \\
\text { and animal } \\
\text { models using } \\
\text { irradiation for } \\
\text { DNA damage }\end{array}$ \\
\hline 25 & Lu et al. & $\begin{array}{l}\text { Targeting thioredoxin } \\
\text { reductase is a basis for } \\
\text { cancer therapy by arsenic } \\
\text { trioxide. }\end{array}$ & $\begin{array}{l}2007 \\
\text { Proc. Natl. Acad. Sci. }\end{array}$ & $\begin{array}{l}\text { An attempt to detect the mechanism by } \\
\text { which ATO acts on medulloblastoma }\end{array}$ & $\begin{array}{l}\text { Functional assays, } \\
\text { evaluation of the } \\
\text { mechanism of } \\
\text { action of ATO }\end{array}$ \\
\hline 26 & Nakamura et al. & $\begin{array}{l}\text { Arsenic trioxide prevents } \\
\text { osteosarcoma growth by } \\
\text { inhibition of GLI } \\
\text { transcription via DNA } \\
\text { damage accumulation }\end{array}$ & $\begin{array}{l}2013 \\
\text { PLoS ONE }\end{array}$ & $\begin{array}{l}\text { Demonstration in human osteosarcoma } \\
\text { lines using real time PCR that ATO reduces } \\
\text { the expression of genes linked to the SHH } \\
\text { pathway including PTCHI, GLII, and GLI2 }\end{array}$ & $\begin{array}{l}\text { Preclinical study, } \\
\text { functional assays } \\
\text { with cell cultures }\end{array}$ \\
\hline 27 & Nasr et al. & $\begin{array}{l}\text { Eradication of acute } \\
\text { promyelocytic leukemia- } \\
\text { initiating cells through } \\
\text { PML-RARA degradation }\end{array}$ & $\begin{array}{l}2008 \\
\text { Nat. Med. }\end{array}$ & $\begin{array}{l}\text { Analysis of the action of ATO and ATRA } \\
\text { in animal and in vitro models relating their } \\
\text { respective mechanisms of action to the } \\
\text { degradation of the PML-RARA protein }\end{array}$ & $\begin{array}{l}\text { Preclinical study, } \\
\text { functional assays } \\
\text { with cell cultures }\end{array}$ \\
\hline 28 & Northcott et al. & $\begin{array}{l}\text { The miR-17/92 } \\
\text { polycistron is up- } \\
\text { regulated in sonic } \\
\text { hedgehog-driven } \\
\text { medulloblastomas and } \\
\text { induced by N-myc in } \\
\text { sonic hedgehog-treated } \\
\text { cerebellar neural } \\
\text { precursors }\end{array}$ & $\begin{array}{l}2009 \\
\text { Cancer Res. }\end{array}$ & $\begin{array}{l}\text { Analysis of } 90 \text { primary medulloblastoma } \\
\text { samples. miR-17/92 expression increased in } \\
\text { the medulloblastoma subgroup associated } \\
\text { with SHH activation compared to } \\
\text { subgroups in which miR- } 17 / 92 \text { was also } \\
\text { elevated due to increased MYC/MYCN } \\
\text { expression }\end{array}$ & $\begin{array}{l}\text { Functional assays, } \\
\text { evaluation of } \\
\text { biological } \\
\text { markers and of } \\
\text { survival curve }\end{array}$ \\
\hline 29 & Northcott et al. & $\begin{array}{l}\text { Medulloblastoma } \\
\text { comprises four distinct } \\
\text { molecular variants }\end{array}$ & $\begin{array}{l}2011 \\
\text { J. Clin. Oncol. }\end{array}$ & $\begin{array}{l}\text { Classification of } 104 \text { primary } \\
\text { medulloblastoma samples based on } \\
\text { similarities in their biological } \\
\text { characteristics in } 4 \text { subgroups }\end{array}$ & $\begin{array}{l}\text { Analysis of the } \\
\text { biological } \\
\text { characteristics of } \\
\text { medulloblastoma } \\
\text { samples }\end{array}$ \\
\hline 30 & Patel et al. & $\begin{array}{l}\text { Are pediatric brain tumors } \\
\text { on the rise in the USA? } \\
\text { Significant incidence and } \\
\text { survival findings from the } \\
\text { SEER database analysis }\end{array}$ & $\begin{array}{l}2014 \\
\text { Child's Nerv. Syst. }\end{array}$ & $\begin{array}{l}\text { Analysis of epidemiological data of } \\
\text { childhood CNS tumors in the United States } \\
\text { up to } 2008\end{array}$ & Historical cohort \\
\hline 31 & Pizem et al. & $\begin{array}{l}\text { Expression of Gli1 and } \\
\text { PARP1 in } \\
\text { medulloblastoma: an } \\
\text { immunohistochemical } \\
\text { study of } 65 \text { cases }\end{array}$ & $\begin{array}{l}2011 \\
\text { J. Neurooncol. }\end{array}$ & $\begin{array}{l}\text { Survival rates were better in patients with a } \\
\text { strong nuclear reaction for Gli1 than in } \\
\text { patients with GLI1-negative } \\
\text { medulloblastomas. Immunohistochemical } \\
\text { detection of Gli1 may be useful for the } \\
\text { identification of medulloblastomas with } \\
\text { activation of the SHH pathway. As revealed } \\
\text { by nuclear reaction for Gli1, the SHH } \\
\text { pathway is activated in about } 60 \% \text { of all } \\
\text { medulloblastomas. In some } \\
\text { medulloblastomas, both SHH and WNT } \\
\text { seem to be activated. PARP1 is highly } \\
\text { expressed in medulloblastomas and may be } \\
\text { useful as a target for increasing the efficacy } \\
\text { of treatment modalities }\end{array}$ & $\begin{array}{l}\text { Analysis of the } \\
\text { biological } \\
\text { characteristics of } \\
\text { medulloblastoma } \\
\text { samples }\end{array}$ \\
\hline 32 & Raffel et al. & $\begin{array}{l}\text { Sporadic } \\
\text { medulloblastomas contain } \\
\text { PTCH mutations }\end{array}$ & $\begin{array}{l}1997 \\
\text { Cancer Res. }\end{array}$ & $\begin{array}{l}\text { A study of } 24 \text { medulloblastomas with } \\
\text { heterozygosity for PTCH suggesting that } \\
\text { inactivation of PTCH function is involved } \\
\text { in medulloblastomas }\end{array}$ & $\begin{array}{l}\text { Analysis of the } \\
\text { biological } \\
\text { characteristics of } \\
\text { medulloblastoma } \\
\text { samples }\end{array}$ \\
\hline
\end{tabular}

Continued on next page

Genetics and Molecular Research 16 (1): gmr16019412 


\section{Table 2. Continued.}

\begin{tabular}{|c|c|c|c|c|c|}
\hline Study & Authors & Study title & Year of publication & Methods, series, and main findings & Type of study \\
\hline 33 & Robinson et al. & $\begin{array}{l}\text { Vismodegib exerts } \\
\text { targeted efficacy against } \\
\text { recurrent sonic hedgehog- } \\
\text { subgroup } \\
\text { medulloblastoma: results } \\
\text { from phase ii pediatric } \\
\text { brain tumor consortium } \\
\text { studies PBTC-025B and } \\
\text { PBTC-032 }\end{array}$ & $\begin{array}{l}2015 \\
\text { J. Clin. Oncol. }\end{array}$ & $\begin{array}{l}\text { Phase II study of the drug Vismodegib } \\
\text { showing activity in adult patients with } \\
\text { medulloblastomas of the SHH group } \\
\text { refractory to first line treatment }\end{array}$ & $\begin{array}{l}\text { Phase II clinical } \\
\text { study }\end{array}$ \\
\hline 34 & Roboz et al. & $\begin{array}{l}\text { Arsenic trioxide induces } \\
\text { dose- and time-dependent } \\
\text { apoptosis of endothelium } \\
\text { and may exert an } \\
\text { antileukemic effect via } \\
\text { inhibition of angiogenesis }\end{array}$ & $\begin{array}{l}2000 \\
\text { Blood }\end{array}$ & $\begin{array}{l}\text { Treatment with arsenic inhibits VEGF in } \\
\text { HELA cell lines and incubation of HUVEC } \\
\text { cells with arsenic prevents the formation } \\
\text { and in vitro differentiation of endothelial } \\
\text { cells. Therefore, arsenic interrupts a } \\
\text { reciprocal stimulatory circuit between } \\
\text { leukemic and endothelial cells, causing } \\
\text { apoptosis of both cell types and inhibiting } \\
\text { the VEGF production of leukemic cells }\end{array}$ & $\begin{array}{l}\text { Preclinical study, } \\
\text { functional assays } \\
\text { with cell cultures }\end{array}$ \\
\hline 35 & Shahi et al. & $\begin{array}{l}\text { Regulation of sonic } \\
\text { hedgehog-GLI1 } \\
\text { downstream target genes } \\
\text { PTCH1, Cyclin D2, } \\
\text { Plakoglobin, PAX6 and } \\
\text { NKX2.2 and their } \\
\text { epigenetic status in } \\
\text { medulloblastoma and } \\
\text { astrocytoma }\end{array}$ & $\begin{array}{l}2012 \\
\text { BMC Cancer }\end{array}$ & $\begin{array}{l}\text { The expression and silencing of GLI1 } \\
\text { resulted in increased regulation of all target } \\
\text { genes in the medulloblastoma cell line, } \\
\text { while only PTCH1 was regulated in } \\
\text { astrocytomas. Methylation of the D2 cyclin } \\
\text { promoter was observed in a significant } \\
\text { number of astrocytoma cell lines ( } 63 \%) \text { and } \\
\text { in primary astrocytoma samples ( } 32 \%) \text {, but } \\
\text { not in all the samples of any type of } \\
\text { medulloblastomas. PTCH1 methylation of } \\
\text { the promoter was less frequently observed } \\
\text { than methylation of the cyclin D2 promoter } \\
\text { in astrocytomas, and in some } \\
\text { medulloblastomas }\end{array}$ & Preclinical study \\
\hline 36 & Shahi et al. & $\begin{array}{l}\text { The sonic hedgehog-GLI1 } \\
\text { signaling pathway in } \\
\text { brain tumor development }\end{array}$ & $\begin{array}{l}2012 \\
\text { Expert Opin. Ther. } \\
\text { Targets }\end{array}$ & $\begin{array}{l}\text { Proteins such as Ptch, SMO, and Gli are } \\
\text { central for the Shh pathway. Other proteins } \\
\text { such as HHIP, Sufu, Bmi -1, cyclin D2, } \\
\text { placoglobin, PAX6, Nkx2.2, and SFRP1 are } \\
\text { not well understood in Shh regulation as } \\
\text { downstream target Gli-1 genes. The study } \\
\text { attempted to elucidate this complex } \\
\text { relationship }\end{array}$ & Preclinical study \\
\hline 37 & Smaele et al. & $\begin{array}{l}\text { An integrated approach } \\
\text { identifies Nhlh1 and } \\
\text { Insml as Sonic } \\
\text { Hedgehog-regulated } \\
\text { genes in developing } \\
\text { cerebellum and } \\
\text { medulloblastoma }\end{array}$ & $\begin{array}{l}2008 \\
\text { Neoplasia }\end{array}$ & $\begin{array}{l}\text { Profile of the expression of the cerebellar } \\
\text { gene of rats aged } 1 \text { to } 13 \text { days revealing a } \\
\text { group of genes whose expression is } \\
\text { correlated with hedgehog (hh) activity } \\
\text { levels. In this set, Insm1 and Nhlh1/NSCL1 } \\
\text { were identified as new HH targets induced } \\
\text { by SHH treatment in in progenitors of } \\
\text { cultured cerebellar granular cells. The } \\
\text { Nhlh1 promoter was observed to bind to } \\
\text { and get activated by the Glil transcription } \\
\text { factor }\end{array}$ & Functional assays \\
\hline 38 & Yang et al. & $\begin{array}{l}\text { Arsenic trioxide inhibits } \\
\text { the Hedgehog pathway } \\
\text { which is aberrantly } \\
\text { activated in acute } \\
\text { promyelocytic leukemia }\end{array}$ & $\begin{array}{l}2013 \\
\text { Acta Haematol. }\end{array}$ & $\begin{array}{l}\text { The Hh pathway is abnormally activated in } \\
\text { APL and is associated with poor prognosis. } \\
\text { ATO can effectively inhibit the expression } \\
\text { of the Hh pathway. The data obtained } \\
\text { provided the first clinical evidence for the } \\
\text { application of ATO in tumors that exhibit } \\
\text { an aberrantly activated Hh pathway }\end{array}$ & Functional assays \\
\hline 39 & Yoon et al. & $\begin{array}{l}\text { Defining a role for Sonic } \\
\text { hedgehog pathway } \\
\text { activation in desmoplastic } \\
\text { medulloblastoma by } \\
\text { identifying GLI1 target } \\
\text { genes }\end{array}$ & $\begin{array}{l}2009 \\
\text { Int. J. Cancer }\end{array}$ & $\begin{array}{l}\text { The authors attempted the identification of } \\
\text { genes linked to Glil in the activation of the } \\
\text { SHH pathway in desmoplastic } \\
\text { medulloblastomas }\end{array}$ & Functional assays \\
\hline
\end{tabular}

AML M3 = acute promyelocytic leukemia M3; CNS = central nervous system; $\mathrm{ATO}=$ arsenic trioxide; $\mathrm{CSF}=$ cerebrospinal fluid; ATRA = all-trans retinoic acid; $\mathrm{PCR}=$ polymerase chain reaction.

Genetics and Molecular Research 16 (1): gmr16019412 


\section{DISCUSSION}

\section{ATO as a Gli inhibitor}

Strategies for the inhibition of SHH pathways are being constantly developed. Initially, the idea was to develop a drug that would function as a central regulator of the SHH pathway by directly acting on the SMO protein. Within this context, cyclopamide was considered. Cyclopamide was first described as a steroidal alkaloid and later found to be an SMO receptor antagonist (Kim et al., 2010). Several other SMO inhibitors were then developed, four of them, i.e., Vismodegib (GDC-0449), NVP-LDE225 (Novartis), IPI-926 (Infinito), and XL-139 (BMS/ Exelis) progressing to phase II clinical assays. All of these compounds act as competitive inhibitors of the cyclopamide ligand (Kim et al., 2010). The response to treatment with these drugs was initially positive; however, cases of drug resistance were observed after a certain period of use. Possible causes of this resistance were reported to be Gli 2 changes, cyclin D1 amplification, and PI3K-AkT-mTOR signaling pathway activation (Kim et al., 2010).

New strategies for the inhibition of the SHH pathway were investigated based on the observation that GLI1 and GLI2 expressions confer a poor prognosis to pediatric MB, with GLI2 playing a central role in SHH activation. GLI2 expression leads to a change in morphology and a reduction in viability, cell numbers, and apoptosis in MB. The GLI1 protein is transcribed together with GLI2 but has no principal action, only representing an activation marker of the pathway, a fact indicating GLI2 as a possible target of therapy (Buczkowicz et al., 2011).

It had been reported that ATO acts on Ewing sarcoma cell lines and MB because of its interaction with GLI; however, the exact mechanism of action was unknown. Beauchamp et al. (2009) demonstrated that the relevant mechanism included direct intranuclear binding of ATO to DNA, with no change in the intracytoplasmic or nuclear GLI protein concentrations (Beauchamp et al., 2011).

The effect of ATO on PML has been well established, with the drug being used widely to achieve remission in induction failure (Nasr et al., 2008). ATO integration with Zn-fingers of the PML protein alters the conformation of the protein and promotes its degradation. Similarly, ATO inhibits tumor growth by inhibiting the ciliary accumulation of Gli 2, promoting its degradation. The combination of itraconazole and ATO for the treatment of MB has been tested in PTCH-positive and TP 53-negative animals, demonstrating synergism with a reduction in tumor volume. ATO in monotherapy or in combination with itraconazole inhibits the SHH pathway by distinct mechanisms (Nasr et al., 2008; Kim et al., 2010).

It has been demonstrated that ATO inhibits tumor growth by blocking the transcription of GLI pathway components. ATO also reduced the expression of genes of the SHH pathway, such as PTCH1, GLI1, and GLI2 in human osteosarcoma cell lines (Nakamura et al., 2013). The same study also reported that treatment with ATO promoted apoptosis of neoplastic cells caused by the accumulation of direct DNA damage. Studies of bone tumor cell lines (Ewing sarcoma) also revealed sensitivity to the use of ATO, with direct binding of GLI1 to the EWSFLI1 oncoprotein (Beauchamp et al., 2011).

Roboz and his collaborators demonstrated that ATO has the ability to induce apoptosis of leukemia cells and endothelial blood vessel cells in a dose- and time-dependent manner (Roboz et al., 2000). In this study model, ATO inhibits endothelial cells by vascular endothelial growth factor (VEGFA) inhibition via a vascular receptor, with the consequent suppression of angiogenesis and tumor growth (Ge et al., 2015). Using the microRNA profile of endothelial

Genetics and Molecular Research 16 (1): gmr16019412 
cells derived from stem cells, miR-126 has been reported to directly and negatively regulate VEGFA signaling through PI3KR2 and SPRED1, both regulators of this pathway (Ge et al., 2015). One of the possible study limitations is the retrospective nature of study reviews on the subject. Although we opted to use several databases with ample literature coverage, some inclusive articles may have escaped our search criteria.

\section{CONCLUSIONS}

New strategies for the treatment of MB are being explored. The SHH pathway and its components, PTCH1, SMO, and SUFU, were first investigated in an attempt to develop a specific drug for the blockade of these pathways. Initially, clinical results of this intervention were positive; however, drug resistance was observed after a period of therapeutic use. In continued attempts at blockade, the Gli gene has been a little explored target. Drugs that directly block Gli could potentially be included in the standard therapeutic scheme (polychemotherapy and/or radiotherapy). With a singular history, ample clinical use, and good CNS penetration, arsenic trioxide is still being investigated today in a field beyond that of leukemias. Preclinical studies of ATO in brain tumors, in which the participation of the SHH pathway is involved, have demonstrated an acceptable profile for the assessment of this drug in animal models of MB both in combination with chemotherapy and as a radiosensitizing agent.

\section{Conflicts of interest}

The authors declare no conflict of interest.

\section{ACKNOWLEDGMENTS}

Nível Superior).

\section{REFERENCES}

Al-Halabi H, Nantel A, Klekner A, Guiot MC, et al. (2011). Preponderance of sonic hedgehog pathway activation characterizes adult medulloblastoma. Acta Neuropathol. 121: 229-239. http://dx.doi.org/10.1007/s00401-010-0780-0

Au WY (2011). A biography of arsenic and medicine in Hong Kong and China. Hong Kong Med. J. 17: 507-513.

$\mathrm{Au}$ WY, Tam S, Fong BM and Kwong YL (2008). Determinants of cerebrospinal fluid arsenic concentration in patients with acute promyelocytic leukemia on oral arsenic trioxide therapy. Blood 112:3587-3590. http://dx.doi.org/10.1182/ blood-2008-06-161000

Au WY, Li CK, Lee V, Yuen HL, et al. (2012). Oral arsenic trioxide for relapsed acute promyelocytic leukemia in pediatric patients. Pediatr. Blood Cancer 58: 630-632. http://dx.doi.org/10.1002/pbc.23306

Beauchamp E, Bulut G, Abaan O, Chen K, et al. (2009). GLI1 is a direct transcriptional target of EWS-FLI1 oncoprotein. J. Biol. Chem. 284: 9074-9082. http://dx.doi.org/10.1074/jbc.M806233200

Beauchamp EM, Ringer L, Bulut G, Sajwan KP, et al. (2011). Arsenic trioxide inhibits human cancer cell growth and tumor development in mice by blocking Hedgehog/GLI pathway. J. Clin. Invest. 121: 148-160. http://dx.doi.org/10.1172/ JCI42874

Boehme KA, Zaborski JJ, Riester R, Schweiss SK, et al. (2016). Targeting hedgehog signalling by arsenic trioxide reduces cell growth and induces apoptosis in rhabdomyosarcoma. Int. J. Oncol. 48: 801-812.

de Bont JM, Packer RJ, Michiels EM, den Boer ML, et al. (2008). Biological background of pediatric medulloblastoma and ependymoma: a review from a translational research perspective. Neuro-oncol. 10: 1040-1060. http://dx.doi. org/10.1215/15228517-2008-059

Genetics and Molecular Research 16 (1): gmr16019412 
Buczkowicz P, Ma J and Hawkins C (2011). GLI2 is a potential therapeutic target in pediatric medulloblastoma. $J$. Neuropathol. Exp. Neurol. 70: 430-437. http://dx.doi.org/10.1097/NEN.0b013e31821b94db

Chang KJ, Yang MH, Zheng JC, Li B, et al. (2016). Arsenic trioxide inhibits cancer stem-like cells via down-regulation of Gli1 in lung cancer. Am. J. Transl. Res. 8: 1133-1143.

Crawford JR, MacDonald TJ and Packer RJ (2007). Medulloblastoma in childhood: new biological advances. Lancet Neurol. 6: 1073-1085. http://dx.doi.org/10.1016/S1474-4422(07)70289-2

Elamin MH, Shinwari Z, Hendrayani SF, Al-Hindi H, et al. (2010). Curcumin inhibits the Sonic Hedgehog signaling pathway and triggers apoptosis in medulloblastoma cells. Mol. Carcinog. 49: 302-314.

Enguita-Germán M, Schiapparelli P, Rey JA and Castresana JS (2010). CD133+ cells from medulloblastoma and PNET cell lines are more resistant to cyclopamine inhibition of the sonic hedgehog signaling pathway than CD133- cells. Tumour Biol. 31: 381-390. http://dx.doi.org/10.1007/s13277-010-0046-4

Falchi L, Verstovsek S, Ravandi-Kashani F and Kantarjian HM (2016). The evolution of arsenic in the treatment of acute promyelocytic leukemia and other myeloid neoplasms: Moving toward an effective oral, outpatient therapy. Cancer 122: 1160-1168. http://dx.doi.org/10.1002/cncr.29852

Fellay CN, Frappaz D, Sunyach MP, Franceschi E, et al. (2011). Medulloblastomas in adults: prognostic factors and lessons from paediatrics. Curr. Opin. Neurol. 24: 626-632. http://dx.doi.org/10.1097/WCO.0b013e32834cd4b1

Ge HY, Han ZJ, Tian P, Sun WJ, et al. (2015). VEGFA expression is inhibited by arsenic trioxide in HUVECs through the upregulation of Ets-2 and miRNA-126. PLoS One 10: e0135795. http://dx.doi.org/10.1371/journal.pone.0135795

Gerber NU, Mynarek M, von Hoff K, Friedrich C, et al. (2014). Recent developments and current concepts in medulloblastoma. Cancer Treat. Rev. 40: 356-365. http://dx.doi.org/10.1016/j.ctrv.2013.11.010

Götschel F, Berg D, Gruber W, Bender C, et al. (2013). Synergism between Hedgehog-GLI and EGFR signaling in Hedgehog-responsive human medulloblastoma cells induces downregulation of canonical Hedgehog-target genes and stabilized expression of GLI1. PLoS One 8: e65403. http://dx.doi.org/10.1371/journal.pone.0065403

Han JB, Sang F, Chang JJ, Hua YQ, et al. (2013). Arsenic trioxide inhibits viability of pancreatic cancer stem cells in culture and in a xenograft model via binding to SHH-Gli. Onco Targets Ther. 6: 1129-1138. http://dx.doi.org/10.2147/ OTT.S49148

Han YG and Alvarez-Buylla A (2010). Role of primary cilia in brain development and cancer. Curr. Opin. Neurobiol. 20: 58-67. http://dx.doi.org/10.1016/j.conb.2009.12.002

Kim J, Lee JJ, Kim J, Gardner D, et al. (2010). Arsenic antagonizes the Hedgehog pathway by preventing ciliary accumulation and reducing stability of the Gli2 transcriptional effector. Proc. Natl. Acad. Sci. USA 107: 1343213437. http://dx.doi.org/10.1073/pnas. 1006822107

Kool M, Korshunov A, Remke M, Jones DT, et al. (2012). Molecular subgroups of medulloblastoma: an international meta-analysis of transcriptome, genetic aberrations, and clinical data of WNT, SHH, Group 3, and Group 4 medulloblastomas. Acta Neuropathol. 123: 473-484. http://dx.doi.org/10.1007/s00401-012-0958-8

Korshunov A, Remke M, Werft W, Benner A, et al. (2010). Adult and pediatric medulloblastomas are genetically distinct and require different algorithms for molecular risk stratification. J. Clin. Oncol. 28: 3054-3060. http://dx.doi. org $/ 10.1200 / \mathrm{JCO} .2009 .25 .7121$

Leonard JM, Ye H, Wetmore C and Karnitz LM (2008). Sonic Hedgehog signaling impairs ionizing radiation-induced checkpoint activation and induces genomic instability. J. Cell Biol. 183: 385-391. http://dx.doi.org/10.1083/ jcb. 200804042

Lu J, Chew EH and Holmgren A (2007). Targeting thioredoxin reductase is a basis for cancer therapy by arsenic trioxide. Proc. Natl. Acad. Sci. USA 104: 12288-12293. http://dx.doi.org/10.1073/pnas.0701549104

Nakamura S, Nagano S, Nagao H, Ishidou Y, et al. (2013). Arsenic trioxide prevents osteosarcoma growth by inhibition of GLI transcription via DNA damage accumulation. PLoS One 8: e69466. http://dx.doi.org/10.1371/journal. pone.0069466

Nasr R, Guillemin MC, Ferhi O, Soilihi H, et al. (2008). Eradication of acute promyelocytic leukemia-initiating cells through PML-RARA degradation. Nat. Med. 14: 1333-1342. http://dx.doi.org/10.1038/nm.1891

Northcott PA, Fernandez-L A, Hagan JP, Ellison DW, et al. (2009). The miR-17/92 polycistron is up-regulated in sonic hedgehog-driven medulloblastomas and induced by N-myc in sonic hedgehog-treated cerebellar neural precursors. Cancer Res. 69: 3249-3255. http://dx.doi.org/10.1158/0008-5472.CAN-08-4710

Northcott PA, Korshunov A, Witt H, Hielscher T, et al. (2011). Medulloblastoma comprises four distinct molecular variants. J. Clin. Oncol. 29: 1408-1414. http://dx.doi.org/10.1200/JCO.2009.27.4324

Patel S, Bhatnagar A, Wear C, Osiro S, et al. (2014). Are pediatric brain tumors on the rise in the USA? Significant incidence and survival findings from the SEER database analysis. Childs Nerv. Syst. 30: 147-154. http://dx.doi. org/10.1007/s00381-013-2307-1

Genetics and Molecular Research 16 (1): gmr16019412 
Pizem J, Popovic M and Cör A(2011). Expression of Gli1 and PARP1 in medulloblastoma: an immunohistochemical study of 65 cases. J. Neurooncol. 103: 459-467. http://dx.doi.org/10.1007/s11060-010-0431-2

Raffel C, Jenkins RB, Frederick L, Hebrink D, et al. (1997). Sporadic medulloblastomas contain PTCH mutations. Cancer Res. 57: 842-845.

Rickert CH and Paulus W (2001). Epidemiology of central nervous system tumors in childhood and adolescence based on the new WHO classification. Childs Nerv. Syst. 17: 503-511. http://dx.doi.org/10.1007/s003810100496

Robinson GW, Orr BA, Wu G, Gururangan S, et al. (2015). Vismodegib exerts targeted efficacy against recurrent sonic hedgehog-subgroup medulloblastoma: results from phase II pediatric brain tumor consortium studies PBTC-025B and PBTC-032. J. Clin. Oncol. 33: 2646-2654. http://dx.doi.org/10.1200/JCO.2014.60.1591

Roboz GJ, Dias S, Lam G, Lane WJ, et al. (2000). Arsenic trioxide induces dose- and time-dependent apoptosis of endothelium and may exert an antileukemic effect via inhibition of angiogenesis. Blood 96: 1525-1530.

Shahi MH, Afzal M, Sinha S, Eberhart CG, et al. (2010). Regulation of sonic hedgehog-GLII downstream target genes PTCH1, Cyclin D2, Plakoglobin, PAX6 and NKX2.2 and their epigenetic status in medulloblastoma and astrocytoma. BMC Cancer 10: 614. http://dx.doi.org/10.1186/1471-2407-10-614

Shahi MH, Rey JA and Castresana JS (2012). The sonic hedgehog-GLI1 signaling pathway in brain tumor development. Expert Opin. Ther. Targets 16: 1227-1238. http://dx.doi.org/10.1517/14728222.2012.720975

De Smaele E, Fragomeli C, Ferretti E, Pelloni M, et al. (2008). An integrated approach identifies Nhlh1 and Insm1 as Sonic Hedgehog-regulated genes in developing cerebellum and medulloblastoma. Neoplasia 10: 89-98. http://dx.doi. org/10.1593/neo.07891

Taylor MD, Liu L, Raffel C, Hui CC, et al. (2002). Mutations in SUFU predispose to medulloblastoma. Nat. Genet. 31: 306-310. http://dx.doi.org/10.1038/ng916

Wells EM, Khademian ZP, Walsh KS, Vezina G, et al. (2010). Postoperative cerebellar mutism syndrome following treatment of medulloblastoma: neuroradiographic features and origin. J. Neurosurg. Pediatr. 5: 329-334. http:// dx.doi.org/10.3171/2009.11.PEDS09131

Yang D, Cao F, Ye X, Zhao H, et al. (2013). Arsenic trioxide inhibits the Hedgehog pathway which is aberrantly activated in acute promyelocytic leukemia. Acta Haematol. 130: 260-267. http://dx.doi.org/10.1159/000351603

Yoon JW, Gilbertson R, Iannaccone S, Iannaccone P, et al. (2009). Defining a role for Sonic hedgehog pathway activation in desmoplastic medulloblastoma by identifying GLI1 target genes. Int. J. Cancer 124: 109-119. http://dx.doi. $\underline{\operatorname{org} / 10.1002 / \text { ijc. } 23929}$

Genetics and Molecular Research 16 (1): gmr16019412 